\title{
FROM INCUBATION TO MATURITY INSIDE PARKS: THE EVOLUTION OF LOCAL KNOWLEDGE NETWORKS
}

\author{
Isabel Díez-Vial ${ }^{1}$ \\ Universidad Complutense de Madrid \\ Facultad de Ciencias Económicas y Empresariales \\ Departamento de Organización de Empresas \\ 28223 Pozuelo de Alarcón, Madrid (Spain) \\ Phone: +34 913942451 \\ Ikujiro Nonaka Centre, CUNEF Business School \\ diezvial@ccee.ucm.es \\ Ángeles Montoro-Sánchez \\ Universidad Complutense de Madrid \\ Facultad de Ciencias Económicas y Empresariales \\ Departamento de Organización de Empresas \\ 28223 Pozuelo de Alarcón, Madrid (Spain) \\ Phone: +34 913942502 \\ Ikujiro Nonaka Centre, CUNEF Business School \\ mangeles@ccee.ucm.es
}

Isabel Díez-Vial is associate professor of Business Administration at Complutense University of Madrid. Her research topics are clusters, science parks and networks. She has published in Journal of Management Studies, Journal of Small Business Management, Knowledge Management Research \& Practice, Growth and Change, Review of Industrial Organization, The Journal of Technology Transfer, Journal of Business Economics and Management, European Planning Studies and European Management Journal, among others. She belongs to the Irujiko Nonaka Centre focused on knowledge management.

Ángeles Montoro-Sánchez is associate professor of Business Administration at Complutense University of Madrid. Her research topics are strategic alliances and networks, entrepreneurship, science parks and innovation. She has published in Research Policy, International Journal of Technology Management, Service Industries Journal, Canadian Journal of Administrative Science, International Journal of Manpower, Journal of Organizational Change Management, Transport Policy, Journal of Knowledge Management, Knowledge Management Research \& Practice and International Business Review among others. She belongs to the Irujiko Nonaka Centre focused on knowledge management.

\section{Acknowledgements}

Funding for this research was provided by the Spanish Ministry of Economy and Competitiveness (Project ECO2011- 29445 and Project ECO2012-36775), the European Union (Project PIRSES-GA-2013-610350), Santander Bank \& Universidad Complutense de Madrid (Project GR3/14/940376), and Cátedra Bancaja Jóvenes Emprendedores-Universidad Complutense de Madrid.

\footnotetext{
${ }^{1}$ Corresponding author
} 


\begin{abstract}
:
This paper analyses the effect of the evolution of local knowledge networks on the innovative capacity of firms co-located. Using a network dynamic approach, the paper argues that the length of time that firms spend in a science park affects their local knowledge network. By the identification of three stages of local development-incubation, growth and maturity-, this study provides new insights about the role of science parks in both increasing their innovative capacity and promoting the exchange of knowledge among co-located firms. In this sense, science parks have been increasingly considered as a nurturing environment for business startups and lead to the development of growth-oriented firms, not being a consensus about how the length of time the firm spends in the park may affect these benefits.
\end{abstract}

Keywords: Network dynamics, knowledge flows, strength of relationships, innovation, time, science park, Social Network Analysis, trust, centrality in the network. 


\section{INTRODUCTION}

In most countries, one of the objectives of establishing science parks is to provide the infrastructure and administrative support that a firm needs for the process of launching innovative products in the market (Brown \& Mason, 2014; McAdam \& McAdam 2008; Ratinho \& Henriques 2010). The development of networks inside parks which foster the mutual exchange and collective creation of knowledge has become particularly important for a firm's innovative capacity (Löfsten \& Lindelöf 2005). By incorporating sources of knowledge external to the park, firms can more easily convert their knowledge base into successful new products (Expósito-langa, Molina-morales, \& Capó-Vicedo 2011).

In this sense, parks have been increasingly considered as geographically bounded networks where firms and support institutions create a nurturing environment for new business start-ups, and therefore lead to the subsequent development of growth-oriented firms (Chan \& Lau 2005: 1215). However, there are certain doubts about how long a firm should stay in a park, receiving support, and to what point remaining there improves innovation (Clarysse, Wright, Lockett, Van de Velde, \& Vohora 2005). Many parks launch incubation programs where firms can only take part for two or three years, it being considered that firms should graduate after that period. Under this approach, the park helps its firms gain access to marketing and technical and managerial knowledge, as well as many other resources, but once firms learn how to successfully commercialize an innovation they must leave (Allen \& Mccluskey 1990; Rothaermel \& Thursby 2005). Conversely, many other parks allow firms to stay for as many years as they wish, using the argument that they can benefit from the park's infrastructures however long they have been there. Moreover, local knowledge generated collectively tends to evolve over the time a firms remains in the park, so the benefits of the park are highly correlated to the evolution of the local network among co-located firms, and this network is expected to strengthen and consolidate itself over time (Ahuja, Soda, \& Zaheer 2012; Phelps, Heidl, \& Wadhwa 2012).

This research is designed to better understand the benefits of the local network in the park over time. A dynamic network approach is used -e.g. preferential attachment dynamics (Powell, Koput, \& Smith-doerr 1996; Soda, Usai, \& Zaheer 2004), where the evolution of the structure and dynamics of local interactions are mainly driven by endogenous forces. Specifically, the aim of this research is to evaluate how firms differ in their local network at different moments during their time in the park and also how these changes affect their innovative capacity.

In doing so this papers intends to contribute to the existing debate about the benefits of remaining in a park for long periods of time and existing policies (Allen \& Mccluskey 1990; Clarysse et al. 2005; Rothaermel \& Thursby 2005). Interesting conclusions can be obtained as we can assess whether periods longer than the standard incubator time make sense in terms of the benefits associated with local knowledge exchange. We build on recent research into the dynamics of the network (Ahuja et al. 2012; Balland, De Vaan, \& Boschma 2013) since this allows us to understand, from a longitudinal perspective, how changes in the social context in which firms are embedded influences their behavior in terms of knowledge exchange and innovation. Because of this, this paper deviates from the mainstream literature of static local research to respond to the increasing need for studies that examine the evolution of local knowledge networks (Tel War, 2013).

This paper also focuses on the exchange of knowledge between firms rather than on the direct transfer of scientific knowledge from universities to industry, as most papers do (Mosey, Lockett, \& Westhead 2007). Scientific knowledge is not the only relevant knowledge for innovation because firms require other types of knowledge such as commercial intelligence, client preferences, failures in the product offered, how to run a business, etc. (Hansson, Husted, 
\& Vestergaard 2005; Sammarra \& Biggiero 2008). Innovation is facilitated by the interaction and recombination of different sources of knowledge in addition to that from the university, forming a network among firms. The studies that have taken into account these networks in the park are inconclusive about their importance (Chan \& Lau 2005; Hansson et al. 2005; Phillimore 1999) in part due to the fact that they are lacking a time aspect.

Finally, in this research we evaluate the role of a firm's network using social network analysis (SNA). Geographically bounded networks are being increasingly evaluated using SNA tools (Boschma \& Ter Wal 2007; Sammarra \& Biggiero 2008), but little research has yet been done on science and technology parks. Most empirical studies trying to measure local networks inside parks have tended to consider them either in an aggregate form, asking the firm for its overall contacts and relationships, or at a dyadic level, asking about specific relationships. In any case, there has not really been an attempt to map from whom the firms learn or the relationship that each firm establishes with other members of the networks.

This paper is structured into the following sections: the theoretical framework is presented in section two. Section three offers a description of the Madrid Science Park sample, an explanation of the measurement of the variables and shows the main results obtained. Section four extracts the main conclusions and management implications.

\section{THEORETICAL FRAMEWORK: A FIRM'S KNOWLEDGE TRANSFER OVER TIME}

The existing literature has highlighted the importance of knowledge transfers among networked firms in terms of increasing innovation (Ahuja 2000; Hansen 1999). Rather than studying the firm as an autonomous and self-reliant agent, the firm and its innovative capacity can be considered the result of the network of relationships it has developed over time (Phelps et al. 2012). A firm's capacity to introduce new products into the market depends on the structure of the ties created among different agents, as well as the type of relationships they develop, such as friendship, commercial transactions, trust based cooperation agreements, etc. (Bell \& Zaheer 2007; Ter Wal \& Boschma 2009).

Specifically, in the context of parks firms establish a network that is also geographically bounded, which means that knowledge can flow more easily than it goes between more widely dispersed networked firms (Boschma 2005; Ter Wal 2014). Face to face interactions, informal meetings, attendance at conferences and seminars, and shared services foster mutual understanding and the sharing of knowledge among firms (Mian 1996). They also develop shared common contexts, codes and values, along with a greater degree of trust and this fosters knowledge flows between firms, making communication easier (Zaheer \& Bell 2005).

From a dynamic perspective it has been observed that networks evolve over time and that this evolution is determined by a path dependent process, as previous links condition future ones (Balland et al. 2013). In particular, the formation of new relationships inside a network tends to follow a preferential attachment logic which reflects the tendency of central firms to become more central over time, attracting new firms to their direct network (Powell, White, Koput, \& Owen-Smith 2005).

A central position in the network implies that the firms have many direct contacts with whom to exchange knowledge, and central firms have access to a broader range of technical, managerial and marketing knowledge so they can complement their own knowledge and experience with that of their connected firms (Powell et al. 1996). Firms in central positions also tend to generate more visibility, status and power inside the network, which makes it easier for them to obtain institutional support and resources such as money, technology, machinery or public funds (Gulati \& Gargiulo 1999). When a new firm enters the park it tends to establish 
links with the firms already located there, ideally with firms in central positions inside the network. If firms increase their direct relationships, they will benefit from moving into more central positions or being able to consolidate these (Powell et al. 2005).

However, as firms increase the time they have spent in the park they not only increase the number of relationships but also tend to reinforce these relationships by increasing the level of trust, commitment and a certain emotional attachment (Ahuja et al. 2012). Firms need time to increase the strength of their relationships. Following (Gulati 1995), firms repeating interactions with other co-located firms tend to develop trust and this induces firms to behave loyally, therefore reducing the mutual fear that others will act opportunistically. Firms tend to reinforce their local relationships with frequent visits to and meetings with other firms, or informal encounters, and with personal proximity, which increases the willingness of firms to share knowledge (Molina-Morales \& Martínez-Fernández 2009). In this environment the opportunism risk is reduced, firms tend to find more opportunities and time for knowledge transfer and there is a feeling of reliability and positive expectations about future relations (Levin \& Cross 2004; Phelps et al. 2012). Based on that, we can propose that:

Hypothesis 1a: “More time in the park increases a firm's central position in the local network".

Hypothesis 1b: "More time in the park strengthens the relationships formed".

Taking into account the above arguments, it could be expected that as firms spend more time in the park they will increase their innovative capacity. Many studies have found that the more links a firm develops, the greater its innovative performance because it has access to more sources of knowledge and these are useful when introducing products in the market (Ahuja 2000; Owen-Smith \& Powell 2004). In a similar vein, the strength of the relationship tends to increase a firm's willingness to share knowledge with others (Levin \& Cross 2004). However, firms need a process for gaining knowledge from others based on being able to develop, communicate and interpret this knowledge (Robertson \& Langlois 1995) and apply it in the development of new products. This is facilitated by a kind of isomorphic process that co-located and tied firms tend to follow (Uzzi 1996).

Logically, the greater the centrality of the firm and the stronger its relationships, the greater the amount of knowledge received. Nevertheless, the impact of the knowledge received through the network on a firm's innovative capacity will vary depending on the time spent in the park. First, an excessive number of relationships and strength in the local network leads to the wellknown problem of over-embeddedness, by which firms tend to be "locked-into" local networks and this reduces their innovative capacity (Uzzi 1996). Local relationships, while providing a great deal of knowledge, tend to be redundant, time consuming, and dilute the focus on other external sources of knowledge which could be important for the firm (Burt 1992; Hansen 1999). As a consequence, increasing the strength and number of local links may have an increasingly positive effect up to a point, after which it can become neutral or even negative (MolinaMorales \& Martínez-Fernández 2009; Uzzi 1996).

Second, firms are not always capable of identifying and incorporating relevant knowledge provided by the network into their products. Firms need to accumulate experience about both their own business and the rules that govern local interactions before they can fully absorb external knowledge (Teece et al., 1997; Zahra \& George, 2002). Finally, firms inside the park do not always need knowledge from other co-located firms with the same intensity. The synergistic effect of the network tends to be associated with situations in which there are differences in skills, experience and knowledge across the network that require a complementarity in the exchange of knowledge (Robertson \& Langlois 1995). Firms with significant experience do not depend as much on the knowledge and perspectives of local firms in the park, so establishing relationships with local exporters does not help to improve their 
innovative capacity. Moreover, they can establish relationships with external agents that provide new sources of knowledge and reduce the lock-in risk (McEvily \& Zaheer, 1999; Molina-Morales \& Martínez-Fernández, 2009).

Taking into account these arguments, we can propose that:

Hypothesis 2a: "Increases in the centrality position increases the knowledge received but it has a varying impact on innovation over time"

Hypothesis 2b: "Increases in the strength of the relationships created increases the knowledge received but it has a varying impact on innovation over time"

\section{EMPIRICAL EVIDENCE: THE CASE OF THE MADRID SCIENCE PARK}

We have gathered information from the Madrid science park. This park is a non-profit foundation created in 2001 by the Autonomous University of Madrid and the Complutense University of Madrid with the support of other organizations. The aim of the Madrid science park is to promote research, development and innovation, offering an intensive program of preincubation, incubation and acceleration. In this context, new companies consolidate their projects and prepare to compete in the market.

We gathered the information using a one hour structured interview with managers from firms located in the Park. In particular, we generated a questionnaire that we pre-tested and discussed with firms in the Park and then used as the basis for interviewing managers. The number of firms established and operating during the information-gathering period was 94 . However, we obtained information about the network from 78 firms, which represents $83 \%$ of the total. Certain data, those relating to our dependent variable, innovation, are missing for two firms, so the final sample is 76 firms.

\subsection{Measurement}

\subsubsection{Time in the park}

There is no uniformly accepted definition of a science park and there are several similar terms used to describe similar developments, such as research park, technology park, innovation center, science park incubator, etc. (Löfsten \& Lindelöf 2005). In addition, several definitions can be found in the literature, each placing the emphasis on the specific objective pursued: to promote the formation of new firms, improve the performance of the local economy, and favor the transfer of technology from universities to firms, among others (Westhead \& Batstone, 1998).

In part due to this terminological confusion and variety of objectives, it is not easy to identify relevant time frames that can take into account the expected evolution of firms inside parks. Each definition and objective has a different time frame associated with it. So, some of them are mainly incubators which are designed to allow a short stay of the new ventures, while others science parks are not generally associated with a limited length of stay. Regarding the first ones, incubation periods are expected to be short, after which time firms are given an incentive to leave through exit graduation programs or exit policies that encourage them to move away from the incubators. This is the case of incentives based on helps with leasing premises, or replacing these firms with others whose need is greater (Allen \& Mccluskey 1990; Clarysse et al. 2005). Nevertheless, most science parks are not only incubators but also facilitators of business development, so there is no exit policy and firms can remain in the park as long as they consider it beneficial to their business. In fact, Rothaermel \& Thursby (2005) have found that firms staying longer in an incubator tend to generate significantly higher revenues. In the case of 
Spanish science parks, and following the definition of the Spanish Science and Technology Parks Association (Asociación de Parques Científicos y Tecnológicos de España, APTE), science parks are projects generally associated with a physical space that: 1) maintains formal and operational links with universities, research centers and other higher education institutions; 2 ) is designed to encourage the formation and growth of knowledge-based companies; and 3) has a stable management that promotes technology transfer and innovation among businesses and organizations using the park.

Taking into account these considerations and following to Rothaermel \& Thursby (2005), in this study we have established three broad times frames: i) from 0 to less than 3 years in the park; ii) 3 to 6 years and iii) more than 6 years. The first period, from 0 to less than 3 years in the park, can be considered an incubation period, as firms have just arrived in the park and they are generally trying to commercialize new products. The length established for this first incubation period is a conservative estimate as most firms are expected to complete this stage in at most 2 years, and firms in incubators not graduating in 2 years can even be considered a failure. After it, we have split the post-incubator stage into two periods, establishing the 6th year as the cut-off point for differentiating them: the growth period (3 to 6 yerars), during which in theory firms tend to develop new local relationships and consolidate the existing ones; and the maturity period (more than 6 years) when firms have extensive experience in the local network as well as in launching new products in the market.

\subsubsection{Social Network Analysis and the local knowledge network}

In this research we measure the knowledge network using a widely used methodology: Social Network Analysis (SNA) (Borgatti, Everett, \& Freeman 2002). SNA measures knowledge flows among firms as well as different aspects of the one-to-one relationships that firms establish with different agents. These kinds of relational data were collected through a 'roster recall' method: each firm was presented with a complete list (roster) of the other firms and institutions in the science park, and they were asked about their relationship with each of these (Giuliani \& Bell 2005; Ter Wal \& Boschma 2009). As a consequence, we arrived at each variable by first creating a matrix in which each cell contains information about the relationship between each pair of organizations. In our research we have valid information for 76 firms, but these firms have developed links with other firms surveyed but providing incomplete data (2 firms), with firms not surveyed (41), and with 9 institutions. As a consequence, for each variable we construct a 128x128 matrix where cell $i j$ represents any characteristic of the relationship between organization $i$ and organization $j$.

To measure knowledge sharing among organizations in the science park, and based on previous literature (Bell \& Zaheer, 2007; Boschma \& Ter Wal, 2007; Giuliani \& Bell, 2005; Hansen, 1999; McEvily \& Zaheer, 1999; Molina-Morales, Capó-Vicedo, Tomás-Miquel, \& ExpósitoLanga, 2012; Morrison, 2008), we asked each manager to indicate the organizations from which they had received different kinds of knowledge over the last 2 years:

$\mathrm{Q}_{1}$ : From which of the local organizations mentioned in the roster have you received technical knowledge such as advice about new production processes, product development, or more efficient machinery? (0: no knowledge exchange; 1: very low intensity and frequency to 7: very high intensity and frequency).

We measure the knowledge received by the focal firms by adding up the amount of knowledge that the firm has received inside the park (Giuliani 2011). In particular, from $\mathrm{Q}_{1}$ we can discover not only with whom the firm has relationships, but also how much knowledge it has received over the past two years, and this measure has been included in the study. We estimate in the following way: 


$$
K N_{k}=\sum_{i=1}^{n} d\left(p_{i}, p_{k}\right)
$$

Where $d\left(p_{i}, p_{k)}\right.$ takes a value from 0 to 7 depending on the answer given in $\mathrm{Q}_{1}$ for the relationship between $\mathrm{p}_{\mathrm{i}}$ and $\mathrm{p}_{\mathrm{k}}$.

Figure 1 shows a graphical representation of these relationships, where each connection between two organizations means that knowledge has passed from one to the other.

$$
\text { ---Insert figure } 1 \text { around here--- }
$$

Once the knowledge network has been mapped, we can also measure centrality in the network. Centrality depends on the number of links between one node and the others in that network. We measured this by counting the number of other firms from which a firm has received knowledge. With this approximation we try to understand the position of the firm simply in terms of the structure of the network, without considering the type of relationships (Ahuja 2000; Freeman 1979).

In particular, centrality is the count of the degree or number of adjacencies for a node, $\mathrm{P}_{\mathrm{k}}$ :

$$
C_{k}=\sum_{i=1}^{n} a\left(p_{i}, p_{k}\right)
$$

Where $a\left(p_{i}, p_{k)}=1\right.$ if and only if $\mathrm{p}_{\mathrm{i}}$ and $\mathrm{p}_{\mathrm{k}}$ are connected by a line in the technical knowledge network or cero otherwise.

We also need to measure the strength of these knowledge relationships inside the science park. As Marsden \& Campbell (1984) have pointed out, it is difficult to design measures of relationship strength given the lack of a precise conceptual definition. According to Granovetter (1973), most of the literature has paid special attention to the level of closeness and friendship in the relationship, the frequency of the relationship and the mutual confiding and acknowledgement of contacts. Following previous studies we measure the strength of the relationships by considering the frequency of the interaction among firms and their degree of friendship (Hansen 1999; Reagans \& Mcevily 2003). This is calculated by asking the following questions:

$\mathrm{Q}_{2}$ : How close/friendly do you feel to the organizations mentioned in the roster? (7 Likert scale).

Q3: How frequently do you have contact with the organizations mentioned in the roster (conferences, informal encounters in meetings, formal or commercial relations, etc.) (7 Likert scale).

$$
\begin{gathered}
C L_{k}=\sum_{i=1}^{n} b\left(p_{i}, p_{k}\right) \\
F R_{k}=\sum_{i=1}^{n} c\left(p_{i}, p_{k}\right)
\end{gathered}
$$

Where $\mathrm{CL}_{\mathrm{k}}$ measures de closeness and $\mathrm{FR}_{\mathrm{k}}$ the friendship; $b\left(p_{i}, p_{k)}\right.$ takes a value from 0 to 7 depending on the answer given in $\mathrm{Q}_{2}$ for the relationship between $\mathrm{p}_{\mathrm{i}}$ and $\mathrm{p}_{\mathrm{k}}$; and $c\left(p_{i}, p_{k)}\right.$ takes a value from 0 to 7 depending on the answer given in $Q_{3}$ for the relationship between pi and $p_{k}$. 
Once we calculated these data for each node $\mathrm{P}_{\mathrm{k}}$, we calculate de mean value of each these values for each point (correlation of $0.891 ; \mathrm{p}<0.01$ ). The variables results

$$
C L_{k}=\frac{C L_{k}+F R_{k}}{\sum_{i=1}^{n} d\left(p_{i}, p_{k}\right)}
$$

Where $d\left(p_{i}, p_{k)}=1\right.$ if and only if $\mathrm{p}_{\mathrm{i}}$ and $\mathrm{p}_{\mathrm{k}}$ have any kind of relationship between them. By dividing the variables with this denominator, we are in fact measuring the strength per relationship avoiding that the higher the number of relationships, the higher the probability of having frequent and close interactions.

\subsubsection{Product innovation}

Innovativeness means a firm's tendency to lead the industry in creating and introducing new products or services and using new technologies to produce these (Zaheer \& Bell 2005). In general, the number of patents that firms have has been broadly considered a good proxy for this measure (Jaffe, Trajtenberg, \& Henderson 1993), but many companies, at least in Spain, do not tend to protect their innovations through patents (Expósito-langa et al. 2011). In our survey we asked companies about their patents, and the low level of patenting confirms this argument.

As a consequence, we have measured innovation as the number of new products or services launched that are not only new for the firm but also for the market (Tsai \& Ghoshal, 1998). This is the same measure as used in the Community Innovation Survey. The Community Innovation Survey is the main data source for measuring innovation in Europe. The main characteristics of this product innovation variable are: mean value 4.026; standard deviation 12.007.

\subsubsection{Other variables}

We have also evaluated other variables that previous studies have identified as having a relevant role in explaining the evolution of the network inside the science park: dependence of the firm on the knowledge provided by the university or management at the Park and the age of the firm.

Dependence on the knowledge provided by the university/management of the Park. Following (Burt, 1992: 54-55), we have measured the dependence of the firm on the knowledge from the university and the management of the Park using a measure that can be defined as the proportion of a firm's network time and energy that directly or indirectly involves the other agent. We then calculated the constraint tool (Borgatti et al. 2002) that creates a new table where cell $i k$ represents the degree to which firm $i$ depends on the knowledge provided by agent $k$. That is, in our research we constructed this matrix with the agents $k$ being the management of the park, when measuring the dependence of firm $i$ on the knowledge of the science park, and the agents $\mathrm{k}$ being the universities and research institutions when measuring the dependence of firm $i$ on universities and research institutions.

The age of the firm has been also taken into account as it has been argued extensively in research that firms change the networks they develop over their life-cycle (McAdam \& McAdam 2008). So it is expected that once the firm has started its new business and is installed in the park it will need local networks to improve its products (Larson \& Starr 1993; Smith \& Lohrke 2008). As firms spend more time in the park, they also get older, so these variables are correlated. As it can be seen in table 2, the age of the firms is 4.03; 6.39; and 8.86 for incubation period, growth period and maturity. But firms can enter in the park not only in their incipient form, but also latter, even once they have consolidated their business, so there are firms older that have just arrived to the park. In particular, most of them (66 of 76 firms) are new ventures (have to 
be 6 years old or younger-Robinson, 1999; Shrader et al., 2000), and 33 of them, 50\% of the firms, have the same age as years in the park.

\subsection{Results}

Table 1 shows the main descriptive statistics for the variables associated with the firms' networks for the whole sample and for the subsamples identified (incubation period, growth period and maturity period). As can be observed, firms have a mean number of 5 direct contacts inside the network, the strength of the relationship takes a mean value of 4.47 out of a maximum of 7, and the knowledge received is 54.8. Comparing different periods, the density and strength of the network that each firm develops increases over time.

\section{---Insert table1 around here---}

In order to test whether there are differences between the main variables that characterize a firm's network over time (hypothesis $1 \mathrm{a}$ and $1 \mathrm{~b}$ ), we need to test for differences between them during the three periods. These differences in means across groups have been estimated using a one-way-Anova for each variable that is expected to change over time. Table 1 presents the main results which show that there are significant differences between the groups in terms of centrality and knowledge received, but not the strength of the relationship.

Along with table 1 we also present the Anova test evaluating differences across periods for the dependent variable, product innovation, and other variables that have been included in the study (Table 2). Although we have not established any hypotheses for these, we consider the results interesting. We observe that in the past 2 years firms have launch 4.02 new products in the market, the mean age of the firms inside the park is 6 years, and firms show a low level of dependence on both the park management and the universities as providers of knowledge. It is interesting to observe that time in the park does not directly affect a firm's innovative capacity, this not being significantly different between time groups. In a similar vein, knowledge dependence on the park's management and universities does not change significantly over time, there being less dependence on the knowledge provided by universities than that provided by the management of the park. Finally, and as expected, age is highly correlated with time in the park.

$$
\text { ---Insert table2 around here--- }
$$

In order to clarify the possible effect of a firm's knowledge network on innovation over time we undertook a path analysis. Path analysis is an extension of multiple regressions that incorporate interactions between independent variables as well as several dependent variables. In our research we have two dependent variables, since we analyze how centrality and strength of the relationships affect both the amount of knowledge received and also how this knowledge received affects innovation. In addition, centrality and strength of the relationship are correlated. Nevertheless, path analysis can only determine whether the data are consistent with the model and cannot establish causality, so these results are illustrative of the theoretical basis proposed.

The results shown in table 3 were run in STATA 12. Since we have a limited number of firms in each period we could only introduce a few variables into the analysis. In any case, this is an explorative analysis that tries to better understand the dynamics of relations inside the park.

$$
\text { ---Insert table } 3 \text { around here--- }
$$

\subsection{Discussion}


Taking into account the results obtain in table 1, 2 and 3, we can confirm hypothesis 2a and 2b. Centrality and strength of the relationship are correlated only in the incubation period. In addition, centrality and the strength of the relationship are positively related to the knowledge received in all periods. In the second stage, when trying to establish a relationship with innovation, we observe that it is only in the growth period that this is significant.

These results also confirm hypothesis 1a because firms tend to increase their centrality over time. Underlying this effect is the existence of some kind of cumulative advantage to those firms with more links that attract new firms and also other central firms, namely preferential attachment. Previous studies have also confirmed the tendency of central local firms to become more central, creating a strong central core inside the network (Gulati \& Gargiulo 1999; Powell et al. 2005). These results are interesting as some recent studies have pointed out that innovative firms might not become more and more central as there is a risk of redundancy in local relationships. As firms increase the number of links locally established, they need to spend time and effort that can impede the establishment of distant relationships.

Contrary to what could have been expected given hypothesis $1 \mathrm{~b}$, there are no significant differences between periods in terms of the strength of the relationships. Although we observe a positive increase over the different periods of time, this difference is not enough to be statistically significant. Nevertheless, we observe that the correlation between centrality and the strength of the relationships is significant and positive only in the incubation period. This result implies that firms invest in strengthening their relationships in the first period, but gradually new ones may become weaker, being more arms-length or market-like than socially embedded. These results are in keeping with studies on entrepreneurship network development which argue that once entrepreneurs have started a new business they tend to increase the limited network that was based around family and friends, forming new exchange relationships based on increasingly weak social relationships (Larson \& Starr 1993; Smith \& Lohrke 2008). Also, several studies have pointed out that firms may prefer to be isolated rather than keeping local relationships as a way to protect their internal resources and knowledge (Morrison \& Rabellotti 2009). As a consequence, some firms may prefer to keep distant and commercial relationships, rather than exchange knowledge locally by trust-based relationships.

---Insert figure 2 around here---

When explaining innovation, we proposed in hypothesis 2 that a firm's local network has a different impact on innovation depending on the time period considered. Firms in the incubation period are investing in these new relationships, trying to increase their centrality and strengthening their relationships, but still cannot fully incorporate external knowledge. Firms in the maturity period have already developed and internalized a great deal of knowledge so more external knowledge does not affect innovation. It is in the growth period when firms can benefit most from the local network. Previous studies have also observed the non-linear effect of local networks on innovation and other performance measures, similar to the one observed in this research (Mcfadyen \& Cannella, 2004; Molina-Morales \& Martínez-Fernández, 2009).

\section{IMPLICATIONS}

Belonging to the park provides several benefits for firms such sharing machinery, procedures and installations, or improving their legitimacy. But above them all, locations inside science park have recently been valued for giving access to valuable sources of knowledge. In this research we have focused on the knowledge network that is internally developed, evaluating how a firm's local network tends to change over the different periods of time spent in a science park. 
Although firms tend to increase their centrality in the network and the strength of their relationships as they evolve and move from one period to another, the dynamics that underlie each period are different. In the incubation period, firms tend to develop new relationships but also try to strengthen them as a way of increasing their mutual trust and developing shared codes and norms. In doing so they are creating a foundation of mutual understanding and knowledge exchange that could translate into higher innovative capacity in the following period.

In the growth period, the firms now have a more central position inside the network and they tend to develop weaker ties than in the incubation period, which implies less effort and time. But it is in this period that a firm's network leads to an increase in innovation, largely due to the investments undertaken previously. This positive effect tends to decline the longer firms spend in the park. In the maturity stage firms have already developed broad experience so they have less to learn from local interactions, and it is even possible for firms to develop external relationships that are more useful when it comes to increasing innovation.

These results have some implications for future research as further study could depend on how parks may affect firms across time. In this sense, it would be interesting to evaluate how different kinds of knowledge may affect firms' product innovation. Firms can either receive incremental or radical new knowledge, affecting their exploitative or explorative learning (Raisch, Birkinshaw, Probst, and Tushman, 2009). It would be interesting to understand the evolution of these elements in a dynamic way across time.

Also, it would be interesting to analyze the role that the university and the management park has not only across time, but also depending if the firm is high innovative or not. In particular, further studies could try to understand how the support of the management park and the university in early stages of life cycle may affect their future development and innovative capacity.

Finally, we consider the evolution of the network created among different firms from different industries. Each industry has its own path dependent evolution process, and it could be the park affect differently to firms due to the stage of the industry and not only due to the time the firm has spent. In this sense, recent studies (e.g. Ter Wall, 2014) have observed how as industries mature they need less proximity. This is explained mainly because the knowledge becomes more codificable. In this research we do not have enough data, but future research could try to consider the stage of the industry as a conditioner of the benefits of the park.

These results have some implications for managers and entrepreneurs based in science parks or planning to enter one. First, it is important to identify the objective being pursued when setting up business in the park. If the firm is looking for advice from the management of the park in relation to different issues, such as launching a product, how to run a business, research about new markets, etc., or would like to obtain basic research knowledge from the university, the time in the park does not seem to be important. Moreover, as a great deal of research about incubators highlights, it might be beneficial to focus on staying just for a few years and then moving the business. Second, if the firm wants to take advantage of knowledge flows that other co-located firms inside the network have created, it needs to invest time and effort in order to develop new links that increase centrality and strengthen relationships. Specifically, firms spending more than 3 years in the park taking part in this local network will have greater innovation due to the knowledge provided by others.

\section{REFERENCES}


Ahuja, G. (2000). Collaboration networks, structural holes, and innovation: A longitudinal study. Administrative Science Quarterly, 45(3), 425-455.

Ahuja, G., Soda, G., \& Zaheer, A. (2012). The genesis and dynamics of organizational networks. Organization Science, 23(2), 434-448.

Allen, D. N., \& Mccluskey, R. (1990). Structure, policy, services, and performance in the business incubator industry. Entrepreneurship: Theory and practice, winter, 61-78.

Balland, P. A., De Vaan, M., \& Boschma, R. A. (2013). The dynamics of interfirm networks along the industry life cycle: The case of the global video game industry, 1987-2007. Journal of Economic Geography, 13(5), 741-765. doi:10.1093/jeg/lbs023

Bell, G. G., \& Zaheer, A. (2007). Geography, networks, and knowledge flow. Organization Science, 18(6), 955-972. doi:10.1287/orsc.1070.0308

Borgatti, S. P., Everett, M. G., \& Freeman, L. C. (2002). Ucinet for Windows: Software for Social Network Analysis. Harvard, MA: Analytic Technologies.

Boschma, R. A. (2005). Proximity and innovation: a critical assessment. Regional Studies, 39(1), 61-74.

Boschma, R. A., \& Ter Wal, A. L. J. (2007). Knowledge networks and innovative performance in an industrial district: The case of a Footwear District in the south of Italy. Industry \& Innovation, 14(2), 177-199.

Brown, R., \& Mason, C. (2014). Inside the high-tech black box: A critique of technology entrepreneurship policy. Technovation, 34, 773-784.

Burt, R. S. (1992). Structural holes: The social structure of competition. Cambridge: Harvard University Press.

Chan, K. F., \& Lau, T. (2005). Assessing technology incubator programs in the science park: the good, the bad and the ugly. Technovation, 25(10), 1215-1228.

doi:10.1016/j.technovation.2004.03.010

Clarysse, B., Wright, M., Lockett, A., Van de Velde, E., \& Vohora, A. (2005). Spinning out new ventures: a typology of incubation strategies from European research institutions. Journal of Business Venturing, 20(2), 183-216. doi:10.1016/j.jbusvent.2003.12.004

Expósito-langa, M., Molina-morales, F. X., \& Capó-Vicedo, J. (2011). New Product Development and Absorptive Capacity in Industrial Districts: A Multidimensional Approach. Regional Studies, 45(3), 319-331. doi:10.1080/00343400903241535

Freeman, L. C. (1979). Centrality in social networks conceptual clarification. Social Networks, 1, 215-239.

Giuliani, E. (2011). Role of technological gatekeepers in the growth of industrial clusters : Evidence from Chile. Regional Studies, 45(10), 1329-1348. 
Giuliani, E., \& Bell, M. (2005). The micro-determinants of meso-level learning and innovation: evidence from a Chilean wine cluster. Research Policy, 34(1), 47-68. doi:10.1016/j.respol.2004.10.008

Granovetter, M. S. (1973). The strength of weak ties. American Journal of Sociology, 78(6), 1360-1380.

Gulati, R. (1995). Does familiarity breed trust? The implications of repeated ties for contractual choice in alliances. Academy of Management Journal, 38(1), 85-112. doi:10.2307/256729

Gulati, R., \& Gargiulo, M. (1999). Where do interorganizational networks come from? American Journal of Sociology, 104(5), 1439-1493.

Hansen, M. T. (1999). The search-transfer problem: The role of weak ties in sharing knowledge across subunits organization. Administrative Science Quarterly, 44(1), 82111.

Hansson, F., Husted, K., \& Vestergaard, J. (2005). Second generation Science Parks: From structural holes jockeys to social capital catalysts of the Knowledge society. Technovation, 25(9), 1039-1049.

Jaffe, A. B., Trajtenberg, M., \& Henderson, R. (1993). Geographic localization of knowledge spillovers as evidenced by patent citations. The Quarterly Journal of Economics, 108(3), 577-598.

Larson, A., \& Starr, J. A. (1993). A network model of organization formation. Entrepreneurship: Theory and practice, 17(winter), 5-15.

Levin, D. Z., \& Cross, R. (2004). The strength of weak ties you can trust: The mediating role of trust in effective knowledge transfer. Management Science, 50(11), 1477-1490. doi:10.1287/mnsc. 1030.0

Löfsten, H., \& Lindelöf, P. (2005). R\&D networks and product innovation patternsacademic and non-academic new technology-based firms on science parks. Technovation, 25, 1025-1037. doi:10.1016/j.technovation.2004.02.007

Marsden, P. V, \& Campbell, K. (1984). Measuring tie strength. Social Forces, 63(2), 453463.

McAdam, M., \& McAdam, R. (2008). High tech start-ups in University Science Park incubators: The relationship between the start-up's lifecycle progression and use of the incubator's resources. Technovation, 28(5), 277-290.

doi:10.1016/j.technovation.2007.07.012

McEvily, B., \& Zaheer, A. (1999). Bridging ties: a source of firm heterogeneity in competitive capabilities. Strategic Management Journal, 20(12), 1133-1156. 
Mcfadyen, M. A., \& Cannella, A. A. (2004). Social Capital and Knowledge Creation : Diminishing Returns of the Number and Strength of Exchange. Academy of Management Journal, 47(5), 735-746.

Mian, S. A. (1996). Assessing value-added contributions of university technology business incubators to tenant firms. Research Policy, 25(3), 325-335.

Molina-Morales, F. X., \& Martínez-Fernández, M. T. (2009). Too much love in the neighborhood can hurt: How an excess of intensity and trust in relationships may produce negative effects on firms. Strategic Management Journal, 30(3), 1013-1023. doi:10.1002/smj

Morrison, A., \& Rabellotti, R. (2009). Knowledge and information networks in an Italian wine cluster. European Planning Studies, 17(7), 983-1006. doi:10.1080/09654310902949265

Mosey, S., Lockett, A., \& Westhead, P. (2007). Technology Analysis \& Strategic Creating network bridges for university technology transfer : The medici fellowship programme Creating Network Bridges for University Technology Transfer : The Medici Fellowship Programme. Technology Analysis \& Strategic Management, 18(1), 71-91.

Owen-Smith, J., \& Powell, W. W. (2004). Knowledge networks as channels and conduits: The effects of spillovers in the Boston Biotechnology community. Organization Science, 15(1), 5-21.

Phelps, C., Heidl, R., \& Wadhwa, A. (2012). Knowledge, networks, and knowledge networks: A review and research agenda. Journal of Management, 38(4), 1115-1166. doi:10.1177/0149206311432640

Phillimore, J. (1999). Beyond the linear view of innovation in science park evaluation An analysis of Western Australian Technology Park. Technovation, 19(11), 673-680. doi:10.1016/S0166-4972(99)00062-0

Powell, W. W., Koput, K. W., \& Smith-doerr, L. (1996). Interorganizational and the collaboration locus of innovation: Networks of learning in Biotechnology. Administrative Science Quarterly, 41(1), 116-145.

Powell, W. W., White, D. R., Koput, K. W., \& Owen-Smith, J. (2005). Network dynamics and field evolution: The growth of interorganizational collaboration in the Life Sciences. American Journal of Sociology, 110(4), 1132-1205. doi:10.1086/421508.

Raisch, S., Birkinshaw, J., Probst, G., \& Tushman, M. L. (2009). Organizational Ambidexterity: Balancing exploitation and exploration for sustained performance. Organization Science, 20(4), 685-695. doi:10.1287/orsc.1090.0428 
Ratinho, T., \& Henriques, E. (2010). The role of science parks and business incubators in converging countries: Evidence from Portugal. Technovation, 30(4), 278-290. doi:10.1016/j.technovation.2009.09.002

Reagans, R., \& Mcevily, B. (2003). Network structure and knowledge transfer: The effects of cohesion and range. Administrative Science Quarterly, 48(2), 240-267.

Robertson, P. L., \& Langlois, R. N. (1995). Innovation, networks, and vertical integration. Research Policy, 24(4), 543-562.

Robinson, K.C. (1999). An examination of the influence of industry structure on eight alternative measures of new venture performance for high potential independent new ventures. Journal of Business Venturing, 14, 165-187.

Rothaermel, F. T., \& Thursby, M. (2005). Incubator firm failure or graduation? Research Policy, 34(7), 1076-1090. doi:10.1016/j.respol.2005.05.012

Sammarra, A., \& Biggiero, L. (2008). Heterogeneity and specificity of inter-firm knowledge flows in innovation networks. Journal of Management Studies, 45(4), 800-829.

Shrader, R.C., Oviatt, B.M., McDougall, P.P. (2000). How new ventures exploit trade-offs among international risk factors: lessons for the accelerated internationalization of the 21st century. Academy of Management Journal, 43(6), 1227-1247.

Smith, D. a., \& Lohrke, F. T. (2008). Entrepreneurial network development: Trusting in the process. Journal of Business Research, 61(4), 315-322. doi:10.1016/j.jbusres.2007.06.018

Soda, G., Usai, A., \& Zaheer, A. (2004). Network memory: The influence of past and current networks on performance. Academy of Management Journal, 47(6), 893-906.

Teece, D., Pisano, G., \& Shuen, A. (1997). Dynamic capabilities and strategic management. Strategic Management Journal, 18, 509-533.

Ter Wal, A.L.J. (2013). Cluster Emergence and Network Evolution: A Longitudinal Analysis of the Inventor Network in Sophia-Antipolis. Regional Studies, 47(5), 651-668. doi: 10.1080/00343401003614258

Ter Wal, A. L. J. (2014). The dynamics of the inventor network in German biotechnology: geographic proximity versus triadic closure. Journal of Economic Geography, 14(3), 589-620. doi:10.1093/jeg/lbs063

Ter Wal, A. L. J., \& Boschma, R. A. (2009). Applying social network analysis in economic geography: framing some key analytic issues. Annals of Regional Science, 43(3), 739756. doi:10.1007/s00168-008-0258-3

Tsai, W., Ghoshal, S. (1998). Social Capital and value creation: The role of intrafirm networks. Academy of Management Journal, 41(4), 464-476. 
Uzzi, B. (1996). The sources and consequences of embeddedness for the economic performance of organizations: The network effect. Americal Sociological Review, 61(4), 674-698.

Westhead, P., \& Batstone, P. (1998). Perceived benefits of a managed science park location. Entrepreneurship \& Regional Development, 11(2), 129-154.

Zahara, A. A., \& George, G. (2002). Absorptive capacity: a review, reconceptualization, and extension. Academy of management Review, 27(2), 185-203.

Zaheer, A., \& Bell, G. G. (2005). Benefiting from network position: firm capabilities, structural holes, and performance. Strategic Management Journal, 26(9), 809-825. doi:10.1002/smj.482 
Figure 1. Direct knowledge connections inside the science park

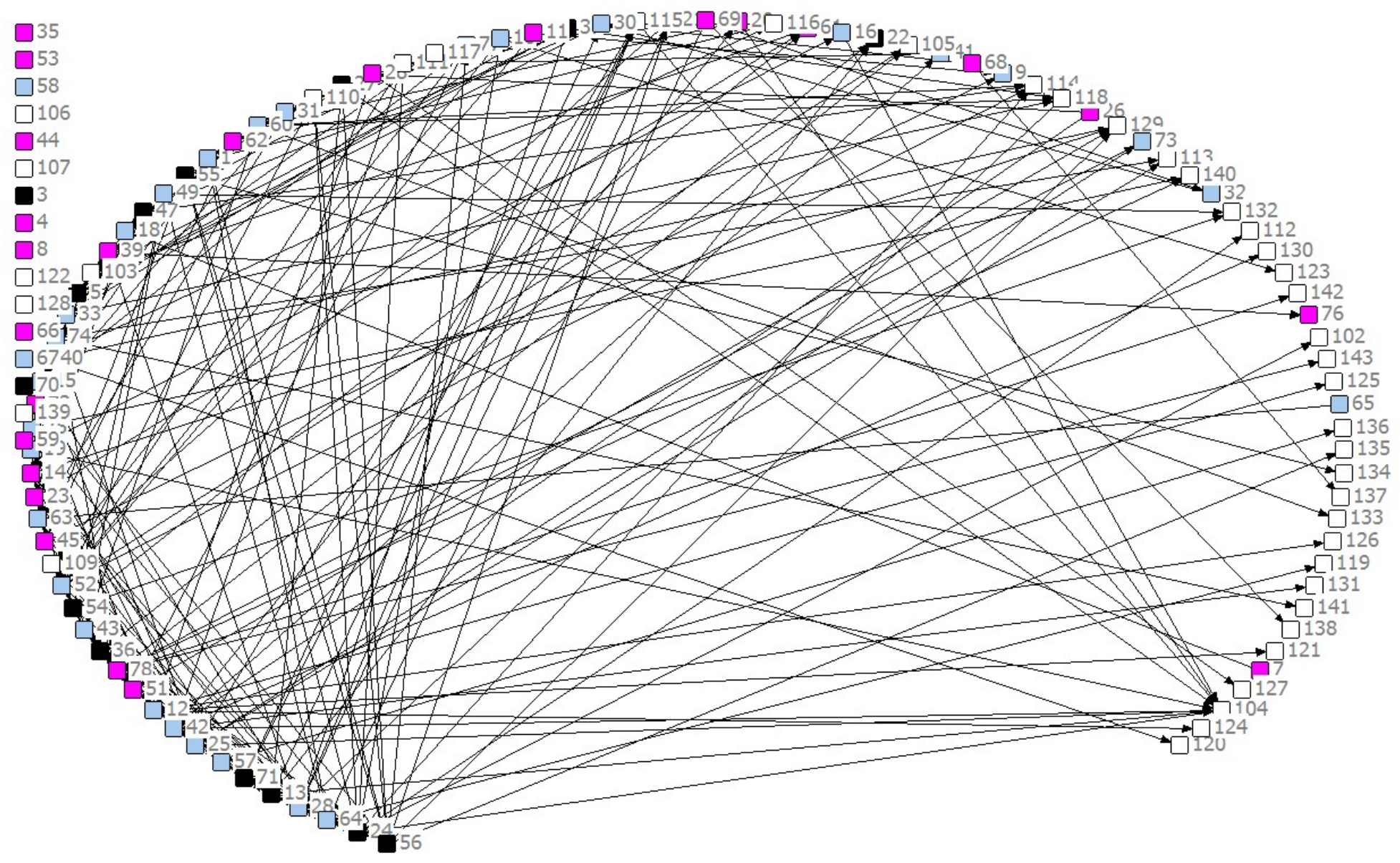

Ordered by the number of direct knowledge connections inside the science park. Pink node: firms with less of 3 years in the park; blue node 3-6 years; black node more than 6 years. 
Table 1. Differencess in the knowledge network across time. Anova

Time in the park

\begin{tabular}{|c|c|c|c|c|c|}
\hline Variables & Total & $\begin{array}{l}\text { Incubation } \\
<3 \text { years }\end{array}$ & $\begin{array}{l}\text { Growth } \\
3 \text { - } 6 \text { years }\end{array}$ & $\begin{array}{l}\text { Maturity } \\
>6 \text { years }\end{array}$ & $\mathrm{F}$ \\
\hline \multicolumn{6}{|l|}{ Centrality } \\
\hline Mean & 5.526 & 4.035 & 6.181 & 6.866 & \multirow{2}{*}{$4.36^{*}$} \\
\hline Std. Dev. & 3.594 & 4.895 & 3.273 & 4.778 & \\
\hline \multicolumn{6}{|l|}{ Strength tie } \\
\hline Mean & 4.471 & 3.828 & 4.859 & 4.819 & \multirow{2}{*}{1.39} \\
\hline Std. Dev. & 2.578 & 2.816 & 2.242 & 2.362 & \\
\hline \multicolumn{6}{|c|}{ Knowledge received } \\
\hline Mean & 54.80 & 41.64 & 55.14 & 78.63 & \multirow{2}{*}{$3.39 *$} \\
\hline Std. Dev. & 45.77 & 40.40 & 38.85 & 60.60 & \\
\hline $\mathrm{N}$ & 76 & 28 & 33 & 15 & \\
\hline
\end{tabular}

${ }^{* *} \mathrm{p}<0.01 ;{ }^{*} \mathrm{p}<0.05 ;+\mathrm{p}<0$. 
Table 2. Differencess of innovation and other variables across time. Anova

Time in the park

\begin{tabular}{|c|c|c|c|c|c|}
\hline Variables & Total & $\begin{array}{l}\text { Incubation } \\
<3 \text { years }\end{array}$ & $\begin{array}{l}\text { Growth } \\
3-6 \text { years }\end{array}$ & $\begin{array}{l}\text { Maturity } \\
>6 \text { years }\end{array}$ & $\mathrm{F}$ \\
\hline \multicolumn{6}{|c|}{ Product innovation } \\
\hline Mean & 4.026 & 3.535 & 5.545 & 1.6 & \multirow{2}{*}{0.59} \\
\hline Std. Dev. & 12.007 & 6.131 & 17.318 & 1.454 & \\
\hline \multicolumn{6}{|l|}{ Age } \\
\hline Mean & 6.013 & 4.035 & 6.393 & 8.866 & \multirow{2}{*}{$6.07 * * *$} \\
\hline Std. Dev. & 4.703 & 4.895 & 4.513 & 2.972 & \\
\hline \multicolumn{6}{|c|}{ Park mangement knowledge dependence } \\
\hline Mean & 0.0844 & 0.0660 & 0.054 & 0.184 & \multirow{2}{*}{0.17} \\
\hline Std. Dev. & 0.163 & 0.124 & 0.083 & 0.290 & \\
\hline \multicolumn{6}{|c|}{ Universities knowledge dependence } \\
\hline Mean & 0.017 & 0.018 & 0.019 & 0.009 & \multirow{2}{*}{0.38} \\
\hline Std. Dev. & 0.036 & 0.034 & 0.042 & 0.024 & \\
\hline $\mathrm{N}$ & 76 & 28 & 33 & 15 & \\
\hline
\end{tabular}

${ }^{* *} \mathrm{p}<0.01 ;{ }^{*} \mathrm{p}<0.05 ;+\mathrm{p}<0$ 
Table 3. Path analysis

\begin{tabular}{|c|c|c|c|}
\hline & \multicolumn{3}{|c|}{ Time in the park } \\
\hline & $\begin{array}{c}\text { Incubation } \\
<3 \text { years }\end{array}$ & $\begin{array}{l}\text { Growth } \\
3 \text { - } 6 \text { years }\end{array}$ & $\begin{array}{l}\text { Maturity } \\
>6 \text { years }\end{array}$ \\
\hline Correlation: Centrality- Strength tie & $0.450 *$ & 0.062 & 0.285 \\
\hline
\end{tabular}

\begin{tabular}{|c|c|c|c|c|c|c|}
\hline \multirow[b]{3}{*}{ Dependent v.: knowledge received } & \multicolumn{6}{|c|}{ Time in the park } \\
\hline & \multicolumn{2}{|c|}{$\begin{array}{c}\text { Incubation } \\
<3 \text { years }\end{array}$} & \multicolumn{2}{|c|}{$\begin{array}{c}\text { Growth } \\
3 \text { - } 6 \text { years }\end{array}$} & \multicolumn{2}{|c|}{$\begin{array}{l}\text { Maturity } \\
>6 \text { years }\end{array}$} \\
\hline & $\beta$ & S.E. & $\beta$ & S.E. & $\beta$ & S.E. \\
\hline Centrality & 4.035 & $1.474^{* *}$ & 5.606 & $1.438 * *$ & 8.220 & $1.686^{* *}$ \\
\hline Strenght tie & 10.708 & $1.376 * *$ & 8.670 & $1.942^{* *}$ & 11.886 & $3.410 *$ \\
\hline Const & -15.641 & $6.694^{*}$ & -21.645 & 13.195 & -35.103 & $18.778^{+}$ \\
\hline $\mathrm{R}^{2}$ & & 0.816 & & 0.562 & & 0.8047 \\
\hline$\left(1-R^{2}\right)^{2}$ & & 0.428 & & 0.661 & & 0.441 \\
\hline Dependent v.: Product innovation & $\beta$ & S.E. & $\beta$ & S.E. & $\beta$ & S.E. \\
\hline Knowledge exchanged & -0.0276 & 0.0698 & 0.250 & $0.105^{*}$ & -0.00635 & 0.0155 \\
\hline Centrality & 0.310 & 0.569 & -1.027 & 1.023 & -0.0383 & 0.156 \\
\hline Strenght tie & 0.710 & 0.889 & 0.486 & 1.452 & 0.101 & 0.260 \\
\hline Const & 0.710 & 2.582 & -4.258 & 7.983 & 1.873 & 1.149 \\
\hline $\mathrm{R}^{2}$ & & 0.0657 & & 0.285 & & 0.097 \\
\hline$\left(1-R^{2}\right)^{2}$ & & 0.9666 & & 0.845 & & 0.950 \\
\hline $\mathrm{N}$ & & 28 & & 33 & & 15 \\
\hline
\end{tabular}

${ }^{* *} \mathrm{p}<0.01 ;{ }^{*} \mathrm{p}<0.05 ;+\mathrm{p}<0$ 
Figure 2. Representation of the path analysis

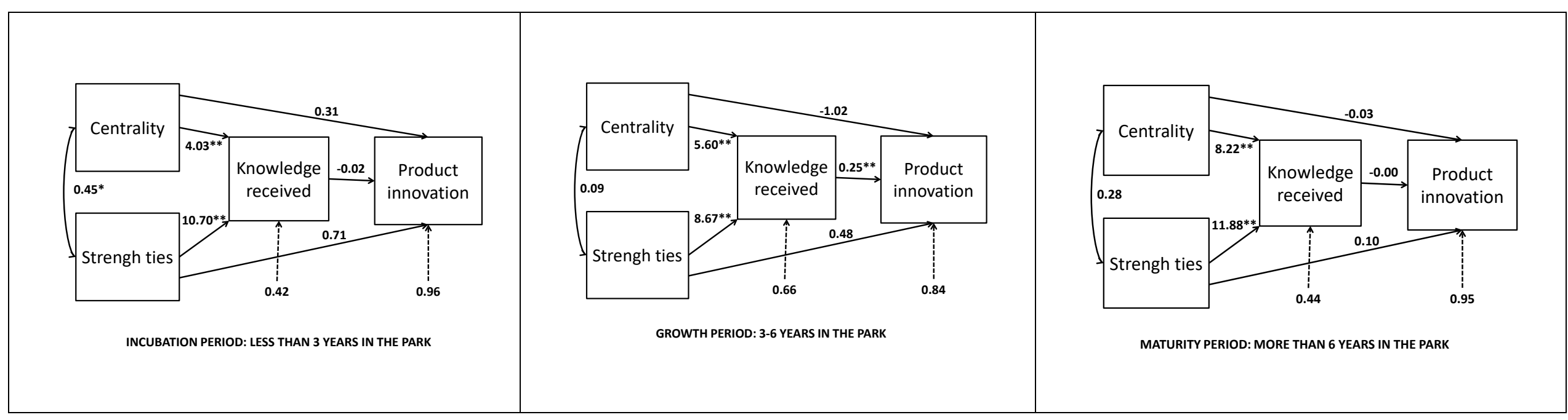

